\title{
Lepidopteran larva consumption of soybean foliage: basis for developing multiple-species economic thresholds for pest management decisions
}

\author{
Regiane Cristina Oliveira de Freitas Bueno, ${ }^{a}$ Adeney de Freitas Bueno, ${ }^{\text {b* }}$ \\ Flávio Moscardi, ' José Roberto Postali Parra ${ }^{\mathrm{d}}$ \\ and Clara Beatriz Hoffmann-Campo ${ }^{b}$
}

\begin{abstract}
BACKGROUND: Defoliation by Anticarsia gemmatalis (Hübner), Pseudoplusia includens (Walker), Spodoptera eridania (Cramer), S. cosmioides (Walker) and S. frugiperda (JE Smith) (Lepidoptera: Noctuidae) was evaluated in four soybean genotypes. A multiple-species economic threshold (ET), based upon the species' feeding capacity, is proposed with the aim of improving growers' management decisions on when to initiate control measures for the species complex.

RESULTS: Consumption by A. gemmatalis, S. cosmioides or S. eridania on different genotypes was similar. The highest consumption of $P$. includens was $92.7 \mathrm{~cm}^{2}$ on Codetec $219 \mathrm{RR}$; that of $S$. frugiperda was $118 \mathrm{~cm}^{2}$ on Codetec $219 \mathrm{RR}$ and $115.1 \mathrm{~cm}^{2}$ on MSoy 8787RR. The insect injury equivalent for S. cosmoides, calculated on the basis of insect consumption, was double the standard consumption by $A$. gemmatalis, and statistically different from the other species tested, which were similar to each other.

CONCLUSIONS: As S. cosmioides always defoliated nearly twice the leaf area of the other species, the injury equivalent would be $\mathbf{2}$ for this lepidopteran species and $\mathbf{1}$ for the other species. The recommended multiple-species ET to trigger the beginning of insect control would then be 20 insect equivalents per linear metre.
\end{abstract}

(c) 2010 Society of Chemical Industry

Keywords: economic injury level; Pseudoplusia includens; Anticarsia gemmatalis; Spodoptera; insect equivalent

\section{INTRODUCTION}

Integrated pest management (IPM) is based on the principle that insecticides must not be applied before economic damage has occurred. Consequently, to enhance growers' decision-making process, the economic injury level (EIL) concept was developed as the lowest population density capable of causing economic damage to plants. ${ }^{1}$ Similarly, the economic threshold (ET) was developed as the population density at which control measures should be started to prevent an increasing pest population from reaching the EIL. ${ }^{2}$ Accurate EILs and ETs are fundamental to increase yield and maintain environmental quality by reducing the unnecessary use of management tactics, especially pesticides. ${ }^{3}$ Pursuing this goal has been a challenge to entomologists because there is a lack of information on this subject regarding different pest species and crops. ${ }^{4}$

Currently, the recommended ETs for lepidopteran larvae on soybean [Glycine max (L.) Merrill] are slightly different around the world. In Brazil, pest control measures are initiated either when 20 large $(\geq 1.5 \mathrm{~cm})$ lepidopteran larvae are counted per sample cloth (1 $\mathrm{m}$ soybean line) or when $30 \%$ defoliation (in the vegetative stage) or $15 \%$ defoliation (in the reproductive state) is observed. ${ }^{5}$
In the United States, it is stated that soybean plants can withstand as much as $35 \%$ defoliation up to the blooming period. However, during this stage, and when pods begin to form and fill out, any foliage loss greater than $20 \%$ will decrease yield. ${ }^{6}$ The tolerance of soybeans for these defoliation levels depends on the cultivar, and such differences are very important for IPM. ${ }^{7}$

The ET based on the number of larvae was originally proposed for the velvetbean caterpillar, Anticarsia gemmatalis (Hübner), which at the time was the most important defoliator insect

Correspondence to: Adeney de Freitas Bueno, Embrapa Soybean, PO Box 231, Londrina, Paraná 86001-970, Brazil.E-mail:adeney@cnpso.embrapa.br

a University of Rio Verde (FESURV), Rio Verde, Goiás, Brazil

b Embrapa Soybean, Londrina, Paraná, Brazil

c Centro de Ciências Agrárias, State University of Londrina, UEL, Londrina, Paraná, Brazil

d Entomology, Phytopathology and Zoology Department, University of São Paulo- ESALQ/USP - Piracicaba, São Paulo, Brazil 
occurring on soybean crops from Argentina to the south-eastern United States. ${ }^{8,9}$ However, nowadays this is not necessarily true in either South America or the south-eastern United States. ${ }^{10,11}$ The occurrence of another insect, the soybean looper [Pseudoplusia includens (Walker)] has increased in soybean fields as a consequence of indiscriminate use of insecticides. ${ }^{11}$ Similarly, species of the genus Spodoptera, such as the southern armyworm, S. eridania (Cramer), as well as S. cosmioides (Walker), are now considered key pests by some Brazilian soybean growers, for example in the states of Goiás and Mato Grosso. ${ }^{12}$ Considering that the capacity for damage of Spodoptera spp. and P. includens might differ from that of $A$. gemmatalis, ${ }^{13}$ an ET based on 20 lepidopteran larvae per sample cloth might not be accurate.

A possible refinement to the EIL concept is to consider injury in standard units, termed injury equivalents. ${ }^{14}$ An insect injury equivalent would be the total injury produced by a single pest over its lifespan. It has been proposed to use injury equivalents for making management decisions for a pest guide, such as a complex of defoliators. ${ }^{14}$ These authors considered the consumption of five soybean-defoliating insects and established injury equivalents to build a multispecies EIL.

The present study compared the foliage consumption of the important soybean pests $P$. includens, S. cosmiodes, S. eridania and $S$. frugiperda, in an attempt to establish injury equivalents and multispecies ETs to be used for management decisions. The defoliation caused by different lepidopterans was also compared in four soybean cultivars, to evaluate possible differences in cultivar tolerance.

\section{MATERIALS AND METHODS}

The experiment was carried out in a factorial randomised block design $4 \times 5$ (four soybean genotypes $\times$ five lepidopteran species) with four replicates, each containing ten lepidopteran larvae. The insects used in the trial were obtained from laboratory colonies where they had been reared for 4-6 generations following their collection in the soybean fields. Lepidopteran larvae to begin laboratory insect colonies were manually collected during the crop season of 2006/2007 (from December 2006 to January 2007) at Rio Verde, State of Goias, Brazil. They were transferred to the laboratory and reared on an artificial diet. ${ }^{15,16}$ The soybean leaflets used in the trials were excised from plants grown in field conditions.

\subsection{Insect colonies}

Colonies of $P$. includens, A. gemmatalis, S. comioides, S. frugiperda and $S$ eridania were kept in the laboratory under controlled environmental conditions $\left(25 \pm 2{ }^{\circ} \mathrm{C}\right.$ temperature, $70 \pm 10 \% \mathrm{RH}$, $14: 10 \mathrm{~h}$ light : dark photoperiod). The insect larvae were reared on an artificial diet, ${ }^{15,16}$ and, after emergence, the adults were fed on a $10 \%$ honey/water solution in cages $(10 \mathrm{~cm}$ diameter $\times 21.5 \mathrm{~cm}$ high). The walls of the cages were covered with A4 paper, used as a substrate for eggs. These eggs were removed daily and used for maintaining the insect colonies.

\subsection{Soybean plots}

The soybean genotypes studied, Conquista (maturity group 8.2), Codetec 219RR (maturity group 8.2), Monsoy 6101 (maturity group 6.1) and Monsoy 8787RR (maturity group 8.7), are the most important cultivars sown in the different Brazilian regions. These genotypes were sowed at Embrapa, Goiânia, Brazil. Four plots $(5 \times 5 \mathrm{~m})$ of each soybean cultivar were manually sowed in rows spaced $0.5 \mathrm{~m}$ apart. The soil is a clayey latosol Typic Haplustox. ${ }^{17}$ Plots with different soybean cultivar were spaced $2 \mathrm{~m}$ from each other and fertilised with $20 \mathrm{~kg} \mathrm{P}_{2} \mathrm{O}_{5} \mathrm{ha}^{-1}$ and $20 \mathrm{~kg} \mathrm{~K}_{2} \mathrm{O} \mathrm{ha}^{-1} .{ }^{18}$ During the entire plant cycle, no pesticides were used, to avoid influencing the insects' biological features. Weeds were manually removed from the area, and insects and diseases occurred homogeneously in all four cultivars and at low levels.

\subsection{Consumption experiment}

The experiment started with first-instar larvae and soybean cultivars at minimum in the $\mathrm{R}_{2}$ growing stage, ${ }^{19}$ with all the cultivars evaluated at the same time. Individual leaflets were collected daily from the sunny sides of the four soybean cultivar plots, and were used to feed the lepidopteran larvae. To standardise the age of the leaflets, only the newest fully expanded leaves were collected at the top of each plant canopy. Leaflets were kept fresh in closed plastic bags and used within $2 \mathrm{~h}$ after excision. Single leaflets were placed on double sheets of moist filter paper in $2.5 \times 11 \mathrm{~cm}$ diameter plastic petri dishes. ${ }^{20}$ Leaflets were replaced daily to avoid excessive dehydration. The insects were maintained in an environmental chamber $\left(25 \pm 2{ }^{\circ} \mathrm{C}\right.$ temperature, $70 \pm 10 \% \mathrm{RH}, 14: 10 \mathrm{~h}$ light: dark photoperiod) up to pupation, which took different times according to the life cycle of each tested species. The sexes of the larvae used in the trial were not taken into consideration.

The soybean foliage area $\left(\mathrm{cm}^{2}\right)$ was determined in a leaf area meter (Model LI-3100; Li-Cor, Lincoln, NE) before and after larval feeding. The daily foliage consumption by each species was then calculated by subtraction. A control leaflet was used for each genotype to estimate leaf dehydration and consequent reduction in leaflet size. This was performed during the entire period of evaluation, by measuring the leaf area $\left(\mathrm{cm}^{2}\right)$ of the control leaflets, and then using these changes to adjust the daily larva consumption results.

The total consumption by each individual larva was recorded for each species, and the average consumption of each replicate was used in the analysis. The insect injury equivalent was calculated by dividing the foliage consumption of each replicate by the average consumption of $A$. gemmatalis on each soybean genotype, which was taken as the standard consumption.

\subsection{Data analysis}

Data were analysed for the assumption of normality ${ }^{21}$ and homogeneity of treatment variance in all parameters. ${ }^{5}$ Lepidopteran larva consumption $\left(\mathrm{cm}^{2}\right)$ and insect injury equivalent data did not follow normality or homogeneity of variance, and needed to be transformed into $\sqrt{X}$ to perform the analysis of variance (ANOVA). Then, the means were compared using Tukey's Studentised range test at $5 \%$ probability for statistical significance. ${ }^{22}$

\section{RESULTS AND DISCUSSION}

Factorial analysis revealed an interaction between the pest species and soybean cultivars for insect foliage consumption $\left(\mathrm{cm}^{2}\right)$ $\left(P_{\text {pest } \times \text { soybean }}=0.0158, \mathrm{df}_{\text {residue }}=172, F=33.46\right)$ (Table 1$)$. The defoliating capacity of $P$. includens and $S$. frugiperda varied among the different soybean genotypes tested (Table 1). Anticarsia gemmatalis, S. cosmioides and S. eridania consumed all the genotypes similarly. However, P. includens foliage consumption was higher for Codetec 219RR, and S. frugiperda consumed larger 
Table 1. Consumption $\left(\mathrm{cm}^{2}\right)$ by lepidopteran larvae on different soybean cultivars

Soybean genotype

\begin{tabular}{|c|c|c|c|c|}
\hline Pest species & Codetec 219RR & MSoy 6101 & MSoy 8787RR & Conquista \\
\hline Anticarsia gemmatalis & $92.6( \pm 4.5) \mathrm{bA}$ & $74.2( \pm 4.2) b c A$ & $94.9( \pm 6.3) \mathrm{cA}$ & $90.0( \pm 3.4) b A$ \\
\hline Pseudoplusia includens & $92.7( \pm 4.5) \mathrm{bA}$ & $63.9( \pm 7.4) \mathrm{CB}$ & $63.9( \pm 7.5) a \mathrm{a}$ & $64.0( \pm 4.5) \mathrm{cB}$ \\
\hline Spodoptera cosmioides & $183.6( \pm 14.9) \mathrm{aA}$ & $184.8( \pm 8.9) \mathrm{aA}$ & $185.4( \pm 5.4) \mathrm{aA}$ & $175.1( \pm 5.7) \mathrm{aA}$ \\
\hline Spodoptera eridania & $107.2( \pm 6.9) \mathrm{bA}$ & $98.3( \pm 11.0) b A$ & $101.9( \pm 5.0) \mathrm{bA}$ & $86.9( \pm 7.2) b A$ \\
\hline Spodoptera frugiperda & $118.0( \pm 6.4) b A$ & $90.0( \pm 9.3) b B$ & $115.1( \pm 5.7) b A$ & $95.4( \pm 8.2) b A B$ \\
\hline CV (\%) & & & & \\
\hline
\end{tabular}

a Means followed by similar upper-case letters in the row and similar lower-case letters in the column are not statistically different using Tukey's Studentised range test at 5 per cent probability. Original data followed by statistics performed on data transformed in $\sqrt{X}$.

leaf areas of Codetec 219RR and MSoy 8787RR compared with MSoy 6101. This indicates that the soybean genotypes have different levels of resistance to outbreaks of lepidopteran larvae. MSoy 6161 may be more resistant to both $P$. includens and $S$. frugiperda, as it was consumed less by both species (Table 1). However, types and mechanisms of resistance need to be further studied in field and laboratory trials. In addition to being attacked by insects to a greater or lesser degree, soybean cultivars can also show different tolerances to various defoliation levels, and this information is crucial for crop protection, ${ }^{7}$ considering that plant resistance or tolerance is environmentally safe and generally compatible with other IPM strategies. ${ }^{23}$

Analysis of soybean leaf consumption data for the different pest species clearly shows the damage potential of Spodoptera spp. The feeding capacity of $S$. cosmioides was nearly double the leaf area consumed by the other lepidopteran species $\left(P_{\text {pest }}<0.0001, \mathrm{df}_{\text {pest }}=4, \mathrm{df}_{\text {residue }}=172, F=33.46\right)$. With the results obtained here, showing that lepidopteran larvae of different species consume different levels of foliage, it can be assumed that soybean plants cannot withstand the same level of infestation by all lepidopteran species. Variable defoliating capacity among larvae was previously reported for soybean lepidopterans: $:^{13}$ Spodoptera exigua (Hübner) (Lepidoptera: Noctuidae) was the least damaging species, consuming $52 \mathrm{~cm}^{2}$ leaf larva ${ }^{-1}$ compared with Trichoplusia ni (Hübner) (Lepidoptera: Noctuidae), P. includens, Heliothis virescens F. (Lepidoptera: Noctuidae), Helicoverpa zea (Boddie) (Lepidoptera: Noctuidae) and A. gemmatalis, which consumed 119, 114, 155, 336 and $84 \mathrm{~cm}^{2}$ soybean leaf larva ${ }^{-1}$ respectively. This differs from the present results, where the studied Spodoptera species (S. frugiperda, S. cosmioides and S. eridania) showed the same or even higher defoliating capacity than A. gemmatalis and $P$. includens (Table 1).

Safe ETs should be below EILs, and are calculated using the formula ${ }^{2}$ EIL $=C / V I D$, where $C$ is the cost of management activity per production unit, $V$ is the market value per production unit, $I$ is injury units per insect per production unit and $D$ is damage per injury unit. ${ }^{2}$ As this formula includes the necessary injury and damage information to calculate accurate EILs, the ET can be adjusted for multiple-species outbreaks of soybean defoliators. The central requirement for developing a multiple-species EIL is that injuries by different species of interest produce a homogeneous physiological response in the plant. Species producing a common injury such as defoliation, for example, constitute an injury guild. ${ }^{14}$ When proposing this adjustment for this guild, it was assumed that $C$ would be the same for all lepidopteran larva species, as the same insecticides could be recommended for their control.
Given that $V$ is the market value, this was also considered to be the same. The ID, usually calculated together, ${ }^{2}$ was the only variable suggested to be changed among the lepidopteran species. In this way, injury by any individual species can be related to injury by another species in the same guild. 7,24

Because the ID of S. cosmioides was double that of the other species, it is appropriate to assume that the EIL, and consequently the related ET, will be half that of the other species studied. Therefore, because $S$. cosmioides caused a higher injury level to soybean plants $\left(P_{\text {pest }}<0.0001, \mathrm{df}_{\text {pest }}=4, \mathrm{df}_{\text {residue }}=172\right.$, $F=33.46)$ compared with the other species, this demonstrates that the ET for multiple species is feasible and would represent an improvement in precision for the grower's management decisions. A. gemmatalis, $P$. includens, S. eridania and S. frugiperda consumed roughly the same leaf area, and therefore showed a similar potential for injury to soybean plants (Table 1).

Considering that these lepidopteran species usually occur together in soybean fields, an insect injury equivalent ${ }^{24}$ based on the different feeding capacity of each pest species might be developed. In this context, the insect injury equivalent was calculated. Taking into account its consumption, A. gemmatalis was chosen as the standard equivalent species, and the $S$. cosmioides insect injury equivalent was statistically different from the others and close to double that of $A$. gemmatalis ( $P_{\text {pest }}<0.0001$, $\left.\mathrm{df}_{\text {pest }}=4, \mathrm{df}_{\text {residue }}=172, F=33.96\right)$ (Table 2). This species was used to calculate the economic threshold (ET) presently in use of 20 lepidopteran larvae $\mathrm{m}^{-1} \cdot{ }^{18}$ In conclusion, the injury equivalent must be 2 for S. cosmioides and 1 for all other species tested. Furthermore, the recommended ET to trigger insect control would be 20 insect equivalents per sample cloth ( $1 \mathrm{~m}$ soybean line), similar to the level proposed for other soybean defoliators. ${ }^{7,24}$

An injury equivalency system as proposed here can sometimes be erratic, mainly because, if insect densities are high, competition can reduce injury rates per individual. This issue should be examined in future studies on ET of soybean pests, focusing on the necessary changes in injury equivalence. This might be achieved by an appropriate adjustment based on the density injury per individual function, easily developed as part of an interactive computer implementation of the multiple-species ET model. ${ }^{25}$ Because the present trials used field-grown leaves, the calculated multiple-species ET presented here is more precise than greenhouse trials. ${ }^{25}$ It is also important to consider that defoliationinduced yield losses correspond more closely to the percentage of light interception reductions than to the percentage of leaf area reductions. ${ }^{26}$ Thus, ET might vary not only among lepidopteran species but also among soybean cultivars. ${ }^{7}$ 
Table 2. Insect injury equivalent calculated for five species of lepidopteran larvae feeding on four soybean cultivars ${ }^{\mathrm{a}}$

Soybean genotype

\begin{tabular}{llccc}
\cline { 2 - 5 } Pest species & Codetec 219RR & MSoy 6101 & MSoy 8787RR & Conquista \\
\hline Anticarsia gemmatalis & $1.00( \pm 0.05) \mathrm{bA}$ & $1.00( \pm 0.06) \mathrm{bA}$ & $1.00( \pm 0.07) \mathrm{bA}$ & $1.00( \pm 0.04) \mathrm{bA}$ \\
Pseudoplusia includens & $1.00( \pm 0.05) \mathrm{bA}$ & $0.86( \pm 0.10) \mathrm{bA}$ & $0.86( \pm 0.11) \mathrm{bA}$ & $0.71( \pm 0.05) \mathrm{bA}$ \\
Spodoptera cosmioides & $1.98( \pm 0.16) \mathrm{aB}$ & $2.49( \pm 0.12) \mathrm{aA}$ & $1.95( \pm 0.06) \mathrm{aB}$ & $1.94( \pm 0.06) \mathrm{aB}$ \\
Spodoptera eridania & $1.16( \pm 0.07) \mathrm{bA}$ & $1.32( \pm 0.15) \mathrm{bA}$ & $1.07( \pm 0.05) \mathrm{bA}$ & $0.97( \pm 0.08) \mathrm{bA}$ \\
Spodoptera frugiperda & $1.27( \pm 0.07) \mathrm{bA}$ & $1.21( \pm 0.13) \mathrm{bA}$ & $1.21( \pm 0.06) \mathrm{bA}$ & $1.06( \pm 0.09) \mathrm{bA}$ \\
CV (\%) & & & 10.6 &
\end{tabular}

${ }^{a}$ Means followed by similar upper-case letters in the row and similar lower-case letters in the column are not statistically different using Tukey's Studentised range test at 5 per cent probability. Original data followed by statistics performed on data transformed to $\sqrt{\mathrm{X}}$.

Spodoptera spp. can also damage pods. In this situation, the usual ET of $10 \%$ damaged pods ${ }^{18}$ must remain unchanged, also to be used to initiate the control measure to prevent an increasing pest population ${ }^{3}$ either at $10 \%$ damaged pods or when 20 insect equivalents are found on the sample cloth (1 $\mathrm{m}$ soybean line).

The importance of the improvement in the ET, as proposed here, needs to be tested in field conditions to evaluate how much this might increase soybean economic profits. Crop losses due to arthropods, even if other management tactics are adopted, would be massive without insecticides. ${ }^{27}$ Moreover, elimination of pesticide use would increase the necessary land area to produce food, leading to destruction of natural habitat and potentially depleting soil, water and energy resources. ${ }^{23}$ The economic sustainability of the agricultural production system would also be affected. ${ }^{28}$ However, pesticides must only be applied when necessary, to avoid problems related to indiscriminate use of chemicals. ${ }^{12}$ In conclusion, a precise ET provided by the refinement proposed here is of theoretical and practical interest for soybean growers, allowing them to combine economic profits with ecological sustainability, as required by modern agricultural practice.

\section{ACKNOWLEDGEMENTS}

The authors would like to thank Embrapa Soja and Embrapa Arroz e Feijão for the support provided. Thanks are also extended to Coordenação de Aperfeiçoamento de Pessoal de Nível Superior (CAPES) for the supporting grant (process 23038.035744/2008-89), and to Janet W Reid, JWR Associates, for the English revision. This paper was approved for publication by the Editorial Board of Embrapa Soja as manuscript 10/2010.

\section{REFERENCES}

1 Stern VM, Smith RF, Van Den Bosch R and Hagen KS, The integrated control concept. Hilgardia 29:81-101 (1959).

2 Higley LG and Pedigo LP, The EIL concept, in Economic Thresholds for Integrated Pest Management, ed. by Higley LG and Pedigo LP. University of Nebraska Press, Lincoln, NE, pp. 9-21 (1996).

3 Pedigo LP and Higley LG, Introduction to pest management and thresholds, in Economic Thresholds for Integrated Pest Management, ed. by Higley LG and Pedigo LP. University of Nebraska Press, Lincoln, NE, pp. 1-8 (1996).

4 Buntin GD, Economic thresholds for insect management, in Economic Thresholds for Integrated Pest Management, ed. by Higley LG and Pedigo LP. University of Nebraska Press, Lincoln, NE, pp. 128-150 (1996).

5 Burr IW and Foster LA, A test for equality of variances. Mimeo Series No. 282, University of Purdue, West Lafayette, IN, 26 pp. (1972).
6 Andrews G, Daves C, Koger T, Reed J, Burdine B, Dodds D, et al., Insect control guides for cotton, soybeans, corn, grain sorghum, wheat, sweet potatoes and pastures. Mississippi State University Extension Service, Publication 2471, 64 pp. (2009).

7 Haile FJ, Higley LG and Specht JE, Soybean cultivars and insect defoliation: yield loss and economic injury levels. Agron J 90:344-352 (1998).

8 Hoffmann-Campo CB, Oliveira LJ, Moscardi F, Gazzoni DL, CorrêaFerreira BS, Lorini IA, et al., Integrated pest management in Brazil, in Integrated Pest Management in the Global Arena, ed. by Maredia KM, Dakouo D and Mota-Sanches D. CABI Publishing, Wallingford and Cambridge, UK, pp. 285-299 (2003).

9 Panizzi AR and Corrêa-Ferreira BS, Dynamics in the insect fauna adaptation to soybean in the tropics. Trends Entomol 1:71-88 (1997).

10 Hamadain El and Pitre HN, Oviposition and larval behavior of soybean looper, Pseudoplusia includens (Lepidoptera: Noctuidae), on soybean with different row spacings and plant growth stages. J Agric Urban Entomol 19:29-44 (2002).

11 Bueno RCOF, Parra JRP and Bueno AF, Biological characteristics and thermal requirements of a Brazilian strain of the parasitoid Trichogramma pretiosum reared on eggs of Pseudoplusia includens and Anticarsia gemmatalis. Biol Cont 51:355-361 (2009).

12 Bueno RCOF, Parra JRP, Bueno AF, Moscardi F, Oliveira JRG and Camillo MF, Sem barreira. Revista Cultivar, Pelotas 55:12-15 (2007).

13 Boldt PE, Biever KD and Ignoffo CM, Lepidopteran pest of soybean: consumption of soybean foliage and pods and development time. J Econ Entomol 68:480-482 (1975).

14 Hutchins SH, Higley LG and Pedigo LP, Injury equivalency as a basis for developing multiple-species economical injury levels. J Econ Entomol 81:1 -8 (1988).

15 Greene GL, Leppla NC and Dickerson WA, Velvetbean caterpillar: a rearing procedure and artificial medium.JEcon Entomo/ 69:487-488 (1976).

16 Parra JRP, Técnicas de Criação de Insetos para Programas de Controle Biológico. FEALQ, Piracicaba, São Paulo, Brazil, 134 pp. (2001).

17 Keys to Soil Taxonomy, 7th edition. USDA, Washington, DC, 644 pp. (1996).

18 Tecnologia de produção desoja: região central do Brasil, Sistemas de produção. Embrapa Soja, Vol. 12. Empresa Brasileira de Pesquisa Agropecuária (Embrapa), Brazil, 280 pp. (2009).

19 Fehr WR, Caviness RE, Burmood DT and Penninton JS, Stage of development descriptions for soybeans, Glycine max L. Merrill. Crop Sci 11:929-931 (1971).

20 Reid JC and Greene GL, The soybean looper: pupal weight, development time, and consumption of soybean foliage. Fla Entomol 56:203-206 (1973).

21 Shapiro SS and Wilk MB, An analysis of variance test for normality. Biometrika 52:591-611 (1965).

22 SAS User's Guide: Statistics, Version 8e. SAS Institute, Cary, NC (2001).

23 Funderburk J, Higley LG and Buntin GD, Concepts and directions in arthropods pest management. Adv Agron 51:125-172 (1993).

24 Hunt TE, Higley LG and Haile FJ, Imported longhorned weevil (Coleoptera: Curculionidae) injury to soybean: physiological response and injury guild-level economic injury levels. J Econ Entomol 96:1168-1173 (2003). 
25 Hammond RB, Pedigo LP and Poston FL, Green cloverworm leaf consumption on greenhouse and field soybean leaves and development of a leaf consumption model. J Econ Entomol 72:714-717 (1979).

26 Board JE, Kumudini S, Omielan J, Piror E and Kahlon CS, Yield response of soybean to partial and total defoliation during the seed-filling period. Crop Sci 50:703-712 (2010).
27 Pimentel D, Agroecology and economics, in Ecological Theory and Integrated Pest Management Practice, ed. by Kogan M. John Wiley \& Sons, Inc., New York, NY, pp. 299-319 (1986).

28 Zilberman D, Schmitz A, Casterline G, Lichtenberg E and Siebert JB, The economics of pesticides usage and regulation. Science 253:518-522 (1991). 